\title{
THE JURISTIC NATURE OF ILOBOLO AGREEMENTS IN MODERN SOUTH AFRICA
}

\author{
Siyabonga Sibisi \\ LLB LLM \\ Lecturer, University of KwaZulu-Natal
}

\section{SUMMARY}

The practice of ilobolo has been referred to by many names, including bridal-price, bridewealth, marriage goods or dowry. These concepts are misleading as they suggest that a woman is being bought. There are sections of society who argue that the practice is unconstitutional as it discriminates against women and must be abolished. There are also sections who argue that the practice of ilobolo is firmly rooted in customary marriages and cannot be dispensed with. They add that the practice is not discriminatory against women as it is men who are required to pay ilobolo and not women. Often the agreement that underlies ilobolo is referred to as the ilobolo contract. This brings into purview the question of the juristic nature of the ilobolo agreement; whether it is a contract or a merely an agreement. A conclusion in this regard is important because it sheds some light on the enforceability of an agreement to pay ilobolo. This article sets out to analyse the juristic nature of the ilobolo agreement and concludes that the ilobolo agreement is a sui generis agreement with legal consequences and should be enforceable in a court of law.

\section{$1 \quad$ INTRODUCTION}

The practice of ilobolo ${ }^{1}$ has often been misunderstood. It has also been referred to by many misleading names, especially when attempts are made to come up with a corresponding English equivalent. Bridal-price, bridewealth, ${ }^{2}$ marriage goods ${ }^{3}$ or dowry are some of the misleading concepts. These are misleading as they suggest that the person in respect of whom the ilobolo is paid is being bought. ${ }^{4}$ This approach is a form of

This practice is also known as bogadi, bohali, xuma, lumalo, thaka, ikhazi, magadi or emabheka depending on the ethnic group concerned. See $s 1$ of the Recognition of Customary Marriages Act 120 of 1998 (Recognition of Customary Marriages Act).

2 The South African Law Reform Commission (SALRC) contemplated using the term "bridewealth". The reason for this was to avoid being seen as preferring one ethnic group over the other. It is interesting to note that the commission considered preferring a foreign concept and almost imposed it. It is submitted that the commission was correct in settling on ilobolo, because it has become a South African concept rather than one belonging to a particular group. See South African Law Reform Commission The Harmonisation of the Common Law and the Indigenous Law: Report on Customary Marriages (1998) 49.

3 Bekker and Buchner-Eveleigh "The Legal Character of Ancillary Customary Marriages" 2017 De Jure 8088.

4 Mndaweni "African Marriages Still at the Crossroads in South Africa" 199023 CILSA 361 366. The author submits that the erroneous view of ilobolo as a purchase of a woman finds 
indirect discrimination on the grounds of gender, as ilobolo is only paid in respect of women, and not men. In simple terms, ilobolo is said to objectify women by comparing them to property that is res in commercio. In addition, it is argued to be indirect discrimination on the ground of culture. As is noted below, ilobolo is firmly rooted in African practices and traditions. Both women and men value and treasure it. To say otherwise is to completely disregard the culture of a majority of people.

Unfavourable opinions on ilobolo are, to a large extent, a result of the incorrect labelling mentioned above. There is a fallible currency of views that the entire practice of ilobolo should be abolished on the ground that it discriminates against women. ${ }^{5}$ The difficulty that these views face is that, as pronounced above, ilobolo is deeply rooted and widely practised by all African ethnic groups across South Africa. ${ }^{6}$ Those who practise ilobolo are adamant that it should stay. Academics submit that should the legislature decide to abolish it, the result will probably be paper law of very little significance, if any. ${ }^{7}$

However, there is sound argument in some of the negative perceptions about ilobolo. Ilobolo is seen to be a financial barrier to those younger men who are emotionally ready to settle down with their partners and start a family, but who are unable to do so because of the expenses involved coupled with the traditional implications of ilobolo. ${ }^{8}$ It must be added that in African culture, it is regarded as disrespectful for a man to take a woman and stay with her without at least paying ilobolo. ${ }^{9}$ There is also a belief that a woman who agrees to stay with a man "for free" undertakes a risk that should the man start abusing her, she may enjoy very little or no support from both her family and her man. ${ }^{10}$ The same may result should their "household" run out of finances.

Nonetheless, despite the negative perceptions about ilobolo, it is submitted that the practice has recently been elevated, thus keeping it abreast with modern ways of life. One has to think no further than a man

its roots in the early Dutch settlers; see, generally, Ngema "Considering the Abolition of Ilobolo: Quo Vadis South Africa?" 20122 Speculum Juris 3039.

5 See, generally, Ngema 2012 Speculum Juris 30; see also Hlophe ("The KwaZulu Act on the Code of Zulu Law, 6 of 1981: A Guide to Intending Spouses and Some Comments on the Custom of Lobolo" 198417 CILSA 163 169), who made a call for the abolition of ilobolo before the constitutional era.

6 One should point out that the practice of ilobolo is not unique to South Africa. The practice is widely understood, especially in southern Africa. Furthermore, it is also not unique to African cultural practices as it is traceable in the Bible.

7 See Hlophe 1984 CILSA 169; Ngema 2012 Speculum Juris 46. Dlamini ("Should iLobolo Be Abolished? A Reply to Hlophe" 198518 CILSA 361 368-370) states: "A law that flies in the face of popular convictions has the potential of being disobeyed. It is equally true that law does not compel action but merely persuades people to a particular course of action. The element of effectiveness is important in a law."

8 Hlophe 1984 CILSA 169 and Dlamini 1985 CILSA 361.

$9 \quad$ Bekker and Coertze Seymour's Customary Law in Southern Africa 4ed (1982) 150.

10 See Bekker and Coertze Seymour's Customary Law 150; Dlamini "The Transformation of a Customary Marriage in Zulu Law" 198316 CILSA 383 387. Dlamini (1985 CILSA 361), seconding Hlophe (1984 CILSA 163), avers that there is no concrete evidence to support the claim that ilobolo ensures good treatment of the wife. 
named Jabulani Mahlangu. The latter, having sat through at least five ${ }^{11}$ ilobolo negotiations for family members, decided to draft a document and named it "llobolo Agreement". ${ }^{12}$ This standard document comprises different sections. It provides for the details of emissaries from both the negotiating families, a record of what was agreed upon and details, including full names and identity numbers, of the intending bride and groom. ${ }^{13}$

This is not the first document of this kind. During 2004, a similar document was introduced by Mpho Lebogo; however, the details of this document are unclear. ${ }^{14}$ It appears that this was rather an online document that focused on quantifying ilobolo.

According to Mahlangu, he has sought and obtained legal opinion to the effect that the document is "legally binding" and will stand up in court. It is also referred to as the "ilobolo contract". Such references not only bring into assessment the document, but also redirect attention to the juristic nature of ilobolo agreements in South African law. This is important, especially currently when matters relating to customary marriages frequently land up in court; often the legal issue turns on ilobolo.

The purpose of this article is to examine the juristic nature of ilobolo in South Africa. Noting that a document, of whatever form, make or nature, containing resolutions from ilobolo negotiations is often referred to as a "lobola contract" or "Iobola agreement", should rules relating to contracts apply to ilobolo? It is trite in our law that contracts are sacred and ought to be performed. ${ }^{15}$ Depending on how we determine the juristic nature of the ilobolo agreement, a person who fails to make right his undertaking to pay ilobolo may be in breach of contract. On the other hand, we may see the resolutions from ilobolo negotiations as merely a social agreement. This too, has legal implications, as is shown below. This article starts by looking at the functions of ilobolo, its various functions providing some insight into its legal nature. It then examines whether ilobolo is a contract or a social agreement. A conclusion is made based on the discussions.

11 Dlamini "Legal Form to Seal Lobolo Agreement" (2019-08-29) Sowetan Live https://www.sowetanlive.co.za/news/south-africa/2019-08-29-legal-form-to-seal-loboloagreement/ (accessed 2020-02-10).

12 Mavundza 'You Can Now Get a Legally Binding 'Lobola Agreement' From Shoprite at R99: Here's What It Entails" (2019-09-02) Business Insider https://www.businessinsider.co.za/ lobola-agreement-contract-2019-8 (accessed 2020-02-02).

13 Qukula "New-Age Lobola Agreement Form Covers All the Legal Bases: For Just R99" (2019-09-09) Cape Talk http://www.capetalk.co.za/articles/360223/new-age-lobolaagreement-form-covers-all-the-legal-bases-for-just-r99 (accessed 2020-02-10).

14 Bregmans Attorneys "Lobola Contract Will End Cost-Of-Cows Rows" (9 May 2014) https://www.bregmans.co.za/lobola-contract-will-end-cost-of-cows-row/ (accessed 0.1202002-10).

15 This is expressed as the sanctity of contract or as pacta sunt servanda. See Tromp Freedom of Contract and the Enforceability of Exemption Clauses in View of Section 48 of The Consumer Protection Act (LLM dissertation, North West University) 2014 32-33; Pillay The Impact of Pacta Sunt Servanda in the Law of Contract (LLM dissertation, University of Pretoria) 20157 and Mupangavanhu "Fairness a Slippery Concept: The Common Law of Contract and the Consumer Protection Act 68 of 2008" 2015 De Jure 116119 on the sanctity of contracts. 


\section{THE FUNCTIONS AND ABUSE OF ILOBOLO}

Ilobolo has three functions: legal functions, social functions and economic functions. ${ }^{16}$ Equally true is that the practice is open to abuse. The discussion below focuses first on the functions of the practice, and then on its abuse.

\section{Legal functions ${ }^{17}$}

It remains debatable whether ilobolo is a sine qua non of a customary marriage. ${ }^{18}$ The South African Law Reform Commission (SALRC) proposed that the practice of paying ilobolo should be made optional and should not be a barrier to a valid customary marriage. ${ }^{19}$ According to the recommendations of the SALRC, consent was to be the only essential of a customary marriage. The problem with consent as a requirement is that in African marriages, marriage is a thing done between two families. To require only the consent of the potential spouses certainly overlooks this essence of African marriages. On the other hand, those who advocated for the retention of the practice of ilobolo argued that there should be something that distinguishes a customary marriage from a civil marriage. ${ }^{20}$ This appears to be the basis for the requirement that a customary marriage must be negotiated and celebrated in accordance with customary law.

Ilobolo is not an express requirement of a customary marriage. Mofokeng argues that ilobolo is a silent requirement of a customary marriage. ${ }^{21}$ This analogy is correct for two principal reasons. First, although section 3(1)(b) of the Recognition of Customary Marriages Act, ${ }^{22}$ which provides for the requirements of a valid customary marriage, is silent on ilobolo, nonetheless the use of the words "must be negotiated" suggests that the legislature had the negotiation of ilobolo and ancillary matters in mind. This view is widely

16 Other authors classify the function of ilobolo differently. Ansell ('Because it's our Culture!' (Re)Negotiating the Meaning of Lobola in Southern African Secondary Schools" 200127 Journal of Southern African Studies 697) identifies material functions, lineage functions, social control functions and identity functions; Rudwick and Posel ("Zulu Bridewealth (Ilobolo) and Womanhood in South Africa" 2015 41(2) Social Dynamics https://www.researchgate.net/publication/281934987_Zulu_bridewealth_ilobolo_and_woma nhood_in_South_Africa (accessed 2020-03-17)) identify compensating parents for the transfer of their daughter's reproductivity and labour, establishing relations between the families, and legitimising and stabilising the marriage. Dlamini (1985 CILSA 361) submits that ilobolo had a psychological function in that, although under the KwaZulu Act and the Code of Zulu law ilobolo was not essential for a civil and customary marriage, Black Africans did regard it as an essential requirement.

17 Dlamini 1983 CILSA 386.

18 Ndlovu v Mokoena 2009 (5) SA 400 (GNP) and Mxiki v Mbata in re: Mbata $v$ Department of Home Affairs unreported case A844/2012 of 23 October 2014 (GP).

19 South African Law Reform Commission The Harmonisation of the Common Law and the Indigenous Law: Report on Customary Marriages (1998) 61.

20 South African Law Reform Commission The Harmonisation of the Common Law and the Indigenous Law 49-53.

21 Mofokeng "The Lobolo Agreement as the Silent Requisite for the Validity of a Customary Marriage in Terms of the Recognition of Customary Marriages Act" 200568 THRHR 277-288.

22 Recognition of Customary Marriages Act 120 of 1998. 
accepted in case law $^{23}$ and academic circles. ${ }^{24}$ Furthermore, it is very difficult to think of any other meaning to attach to the word "negotiated". It certainly means something more than the planning of the wedding.

Secondly, for the purposes of registration of a customary marriage, proof of ilobolo is required. ${ }^{25} \mathrm{~A}$ study of case law shows that what is required is not proof that payment was made, but that it was negotiated and agreed upon. Such proof may take many forms; it may be written proof, ${ }^{26}$ photography, ${ }^{27}$ a standard document (such as the one mentioned in the introduction above) or an affidavit by a person who was part of the negotiations. Thus, ilobolo serves an evidential function. The absence of such proof may lead a registering officer to refuse to register a supposed customary marriage.

It must, however, be stated that the legislature is unequivocal that nonregistration of a customary marriage does not affect its validity. ${ }^{28}$ It is submitted that this is an anomaly because a person who cannot prove a customary marriage for the purposes of registration cannot obtain a marriage certificate. In the absence of a marriage certificate, they cannot access spousal benefits such as maintenance or pension interest. The result is that, as far as other aspects of the law are concerned (for example, pension interest law), such person is not a spouse. This is the case unless such a person is able to persuade the court to make an order directing the registering officer to register the marriage. It is difficult to imagine a situation where a court will condone registration of a marriage that does not meet the requirements.

\section{Social functions}

There are social connotations associated with ilobolo in African culture. ${ }^{29}$ llobolo symbolises the groom's love and respect for his wife. ${ }^{30}$ It is also an indication that the potential groom has respect and high regard for his inlaws. Similarly, families usually receive a bride whose lobolo has been paid with warmth and welcome. The matriarch of the family is usually willing or bound to hand over the baton to the incoming bride. This does not only symbolise continuity of the family, it also symbolises continuity of the larger clan. Of course, continuity is a variable depending on whether the incoming bride will bear children or not. However, in African culture, a bride need not necessarily bear a child to ensure continuity; families do work around this.

23 Fanti v Boto 2008 (5) SA 405 (C). Note that this judgment is criticised for not referring to the provisions of the Recognition of Customary Marriages Act. Nonetheless, it does provide useful insight.

24 Himonga and Nhlapo African Customary Law in South Africa: Post-Apartheid and Living Law Perspectives (2014) 103.

$25 \mathrm{~S} 4(4)(a)$ of the Recognition of Customary Marriage Act.

26 The written proof is also referred to as the "Iobola letter". See Rahlaga v Malatja unreported case no 2015/21836 of 13 May 2016 (GJ); Dalasile v Mgoduka unreported case no $5056 / 2018$ of 2 October 2018 (ECM) par 5-6.

27 Moropane $v$ Southon unreported case 755/2012 of 29 May 2014 (SCA) par 9 and Sengadi $v$ Tsambo; In re Tsambo [2019] 1 All SA 569 (GJ) par 8.

28 S 4(9) of the Recognition of Customary Marriages Act.

29 Dlamini 1985 CILSA 364.

30 Ngema 2012 Speculum Juris 38. 
The latter is a very broad practice that might overburden the scope of this article.

It is often said that ilobolo facilitates the "transfer" of the woman's womb in that her children will now belong to her in-laws. ${ }^{31} \mathrm{~A}$ woman who gives birth out of wedlock does so in her homestead. This means that her offspring belong to her maiden family. It is possible for the father of the child to pay ilobolo for the sole purpose of transferring his child from the maternal family to the paternal family. ${ }^{32}$ This happens where the relationship between the mother and the father has ended.

Ilobolo also establishes a bride's status in her new family. ${ }^{33}$ It initiates the process of making her a full member of the family. It is hereby submitted that mere payment of ilobolo does not conclude a customary marriage. In other words, a bride is not a full member of the family (or a member at all) until a customary marriage, in terms of which the bride is handed over to her inlaws, is concluded. The requirement of the handing-over of the bride is controversial. On the one hand, it is argued that the handing-over of the bride is an indispensable requirement of a customary marriage. This argument must be supported. On the other hand, it is argued that the handing-over of the bride is a variable requirement with which the parties may, if they choose, dispense. These proponents suggest a "symbolic delivery". This symbolic delivery has not been explained, but one supposes that it is a mere intention to transfer. It therefore follows that the proponents of a symbolic delivery see mere payment or agreement to pay ilobolo as the conclusion of the marriage. The Supreme Court of Appeal has not been decisive on this matter, as it has spoken in favour of both arguments.

Ilobolo also functions as a connection between the ancestors of both families. Some families, especially those that adhere to ancestral rituals, burn incense (impepho) before the groom's emissaries leave to inform the groom's ancestors that they are about to depart and the reason for such a departure. If cattle will be given, the cattle are "shown" to the ancestors. If money will be used, the notes will be placed near the incense while the ancestors are being informed. Both cattle and money may be shown to the ancestors. Likewise, the family of the bride, upon receiving the cattle or money, will present the same to their ancestors. It must be stated that it is common practice to inform the ancestors of each step taken leading to the marriage.

\section{Financial function}

Ilobolo also serves a financial function. Indeed, it pays for the various processes that a customary marriage entails. A poor family relies on this payment to prepare for the customary marriage of their daughter. Even families that are above average in wealth fall back on the funds. Nowadays, it is accepted that it is almost impossible to profit from ilobolo as all of it goes

\footnotetext{
Bekker and Coertze Seymour's Customary Law 49.

Sibisi "Breach of Promise to Marry Under Customary Law" 2019 Obiter 340349.

33 Hlophe submits that the main purpose of ilobolo is to ensure proper treatment of the bride in her new home. See Hlophe 1984 CILSA 163; and Ngema (2012 Speculum Juris 37), who adds that ilobolo guarantees good treatment for the bride.
} 
toward the costs of the various events that are associated with a customary marriage. ${ }^{34}$ Nonetheless, as will be seen below, attempts are still made at profiting.

During a customary wedding, particularly a Zulu wedding, the bride gives gifts to selected members of her family-in-law (her family usually receives their gifts during umembeso - a ceremony that occurs at her homestead usually long before the wedding). This is called umabo. ${ }^{35}$ She usually buys some or all of these gifts using the ilobolo fund. Thus, a poor bride relies on ilobolo to make her wedding day memorable. The gifts serve a strategic purpose. They are the bride's way of introducing herself into the family. Since the gifts serve a strategic purpose, the bride must be careful of the quality she prefers for certain people. She does not have a choice as to who among her in-laws must get a gift - she merely receives a list bearing the names of the people for whom she must purchase gifts. ${ }^{36}$

Ilobolo also assures the bride of financial security in the event of a depletion in the finances of her married household. This way she can easily go back to her maiden family and ask for help. The family is likely to assist her out of mutual respect for their son-in-law. This may be seen as returning the respect shown by the groom when he decided to pay ilobolo for his bride; as has been stated above, by doing this, he shows respect for the bride's family.

The money paid during ilobolo is usually depleted by this time. As has been pointed out above, in light of current economic trends, the wedding itself consumes most, if not all, of ilobolo. ${ }^{37}$ If anything remains, it is usually very little. Even if the wedding does not deplete the money, what remains is negligible unless the family is wealthy or the bride was able to fund her own customary wedding without resorting to the ilobolo fund.

Nonetheless, when the bride goes back to her family to ask for financial provision, the family usually draws from its coffers. This happens out of love and pride - pride in the dignity with which their daughter has carried herself all the way to marriage. They find joy in knowing that the money will be used to further the family of a man they regard as honorable. Even if the groom is, for whatever reason, no longer honorable, they are inclined to help their daughter.

A woman's family will be unlikely to provide financially for her if she has decided to live with a man without any ilobolo being paid. ${ }^{38}$ This is not to say that her family dislikes her; instead, it is an indication that they disapprove of her choice to live in "sin". Perhaps the reason for withholding financial assistance is to get her to come back home. It is submitted that a response of this nature is inspired by the belief that the woman is less likely to receive better treatment from a man who has not made a financial sacrifice for her. After all, even if the woman decides to leave, the man has nothing to lose.

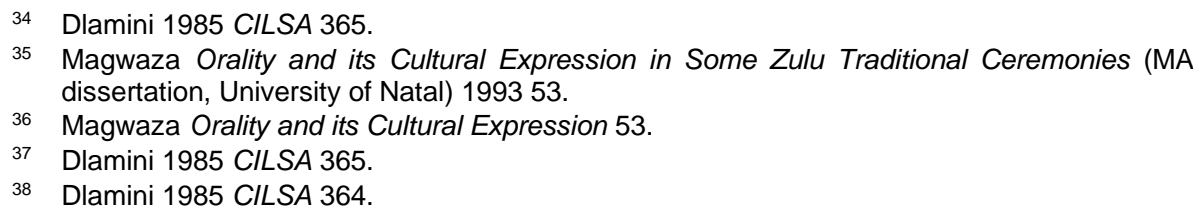


There are exceptional cases where the man is willing to make a financial sacrifice but is unable to do so owing to difficult economic circumstances. This, coupled with treating the woman with respect, may draw a favorable response from the family of the woman. However, in certain cases, the family may overlook the good treatment that their daughter is receiving from the man as their way of indicating their abhorrence of their daughter's choice of a poor man; this is the case especially if there are stable suitors whom she has ignored. It must be stated that these trends are not unique to African families.

In light of the submissions above on the financial function of ilobolo, it is fitting to reflect on the notion that payment or delivery of ilobolo is not a conditio sine qua non of a customary marriage. A lot of money is expended on a customary marriage; it is difficult to imagine a situation where the family of the bride expends taxing amounts on the wedding of their daughter to a man who has not paid anything towards ilobolo. Furthermore, African communities are built on trust and honesty, and a person who promises, must honour his promise. Therefore, the notion that customary marriages merely require an "agreement that ilobolo will be paid" 39 cannot stand.

\section{Abuse of ilobolo practice}

As with everything that involves money, ilobolo practice is open to abuse. As has been elaborated above, ilobolo serves very noble legal, social and financial functions. Unfortunately, these functions are also exploited; the most common form of exploitation involves people who seek to profit from it. Overcharging flows from this form of malpractice. 40 While the amount payable as ilobolo does largely depend on status and wealth, overcharging is impermissible.

In a strained economy, any money paid as ilobolo assists with wedding preparations. The flipside is that those who participate in the negotiations must account for all the money they receive during ilobolo negotiations. Unfortunately, in some sections of our society, patriarchy dominates ilobolo negotiations - only men negotiate ilobolo. ${ }^{41}$ The risk is that the fate of the ilobolo money is left in the hands of an unscrupulous father or uncle who may regard the money as his own and use it for things that will not benefit the bride.

39 See Manthwa "Lobolo, Consent as Requirements for the Validity of a Customary Marriage and the Proprietary Consequences of a Customary Marriage: $N v D(2011 / 3726)$ [2016] ZAGPJHC 163" 2017 Obiter 438439.

40 Hlophe 1984 CILSA 169 and Dlamini 1985 CILSA 361.

41 Patriarchy in ilobolo negotiations featured in Mabena $v$ Letsoalo 1998 (2) SA 1068 (T), where a shameful argument was raised to the effect that the mother of the bride (the only parent) could not validly negotiate the marriage of her daughter simply because, under customary law, a woman does not participate in ilobolo negotiations. The court correctly treated this argument with the contempt that it deserves. It has no place in a South Africa with a justiciable Bill of Rights embodying rights such as equality and dignity. It is submitted that the right to culture does not trump these rights. 


\section{THE LEGAL NATURE OF ILOBOLO}

Despite so much having been said about ilobolo over more than a century, the legal nature of ilobolo remains obscure. It has been pointed out above that there is an evident tendency in academic circles and the judiciary to refer to the agreement underlying ilobolo as a contract. This raises the question of the nature of the ilobolo agreement in South African law. It is trite in our law that, whereas all contracts are agreements, not all agreements are contracts. ${ }^{42}$ The discussions below are limited to whether the ilobolo agreement is a contract or an agreement that falls short of the essence of a contract.

\section{Contract}

A contract is an agreement that is entered into with the intention of creating a binding obligation or obligations. ${ }^{43} \mathrm{~A}$ valid contract must comply with requirements such as agreement, contractual capacity, possibility of performance, legality, formalities, and intention to be bound. ${ }^{44}$ An agreement that is not intended to create a legally binding obligation is not a contract 45 no matter how serious the parties may be. ${ }^{46}$ This being said, not all obligations are legally binding; a distinction is drawn between civil obligations and natural obligations. A civil obligation (obligatio civilis) ${ }^{47}$ entails a right to claim performance that may be enforced through the courts. ${ }^{48} \mathrm{~A}$ natural obligation (obligatio naturalis) ${ }^{49}$ cannot be enforced in a court of law, but it may be enforced indirectly through set-off or a pledge..$^{50} \mathrm{~A}$ natural obligation creates a moral duty to perform, rather than a legal one. ${ }^{51}$

For a contract to be formed, the parties must seriously intend to be bound. 52 In other words, there must be animus contrahendi or an intention to contract. ${ }^{53}$ It is possible to enter into an agreement without intending to be bound. Entering into a contract means that a party must intend certain legal consequences (such as enforcement through specific performance) should

42 See Joubert (General Principles of the Law of Contract (1987) 11), who points out that this notion originated in Roman law. See also Sharrock Business Transactions Law 9ed (2017) 3 .

43 Van der Merwe, Van Huyssteen, Reinecke and Lubbe Contract: General Principles 3ed (2007) 9.

44 Van der Merwe et al Contract 8.

45 Dlamini $A$ Juridical Analysis and Critical Evaluation of Ilobolo in a Changing Zulu Society (doctoral thesis, University of Zululand) 1983315 and Sharrock Business Transactions Law 87.

46 Kerr The Principles of the Law of Contract 5ed (1998) 41.

47 Christie The Law of Contract in South Africa 5ed (2006) 4.

48 Van der Merwe et al Contract 4. One may add that a civil obligation (obligatio) is a legal bond that creates a legal relationship or vinculum iuris. See Christie The Law of Contract 3.

49 Christie The Law of Contract 4.

50 Van der Merwe et al Contract 4. Under Roman law, although a natural obligation was not enforceable like a civil obligation, a party who had received payment in terms of a natural obligation could raise such obligation as a defence against any action for the recovery of the money. See also Christie The Law of Contract 4.

51 Joubert General Principles 11.

52 Bayi and Hawthorne "Colonialisation of Lobolo" 201881 THRHR 576579.

53 Christie The Law of Contract 30. 
the contract not be performed. ${ }^{54}$ Should a party intend otherwise, what is reached is no more than a moral obligation (natural obligation) or an obligation of honour. ${ }^{55}$

In this light, can it be said that an ilobolo agreement is a contract? The answer lies in whether it complies with the requirements of a contract, as briefly set out above. On the face of it, the ilobolo agreement appears to be a contract. However, do parties really intend to create legally binding obligations? In other words, does a party who sends emissaries to negotiate ilobolo intend that, should he fail to perform (pay ilobolo) in terms of whatever agreement is reached, he may be sued? If this is the case, then an ilobolo agreement constitutes a contract. If not, then no contract is created.

To put the discussions above into perspective, it is accepted that ilobolo is an integral part of a customary marriage. ${ }^{56}$ However, our courts are not unanimous on whether a customary marriage requires payment (full or partial) or a mere agreement to pay ilobolo. ${ }^{57}$ It is submitted that there must at least be some payment; otherwise, the negotiations would be an exercise in futility. Can it then be said that a party who sends emissaries to negotiate ilobolo does so without any intention to pay? In such a case, animus contrahendi is lacking and no contract is created. To say that people enter into ilobolo negotiations without intending to be bound undermines the seriousness of the practice and hypocritically overlooks cultural rights as espoused in the Bill of Rights.

Instead, people who send emissaries to negotiate ilobolo do so intending to be bound. To prove this, certain monies are paid as a token, including pula mulomo and ukucela. These monies are not ilobolo, but they precede it. A person who pays pula mulomo and related monies displays an intention to perform in terms of the ilobolo agreement once reached. The question remains, can such intention to perform in terms of the ilobolo agreement be equated with the intention to create a legally binding obligation? In other words, does it turn out that by virtue of intending to perform in terms of an ilobolo agreement, a party may be said to intend to create a legally binding obligation? As has been noted above, this question should be answered in the affirmative only if a party also intends that non-performance be visited by an action for specific performance. In reality, there are no known cases for enforcement of an agreement to pay ilobolo.

One should be careful in interpreting the reason for non-enforcement of an ilobolo agreement. It may be a reflection on the parties' intention; that is, it may indicate that the parties entering into ilobolo negotiations do not intend to create legally binding obligations, thus finalising the argument on whether

\footnotetext{
Sharrock Business Transactions Law 2.

Kerr The Principles 43.

56 Maluleke $v$ Minister of Home Affairs unreported case no 02/24921 of 9 April 2008 (GP) and Himonga and Nhlapo African Customary Law in South Africa 103.

57 Bayi and Hawthorne (2018 THRHR 588) argue that a customary marriage will only occur following partial or full payment of ilobolo. On the other hand, Nkosi and Van Niekerk ("The Unpredictable Judicial Interpretation of Section 3(1)(b) of the Recognition of Customary Marriages Act 120 of 1998: Eunice Xoliswa Ngema $v$ Sifiso Raymond Debengwa (2011/3726) [2016] ZAGPJHC 163 (15 June 2016)" 2018 THRHR 345 346) argue that the father of the bride could waive the right to receive ilobolo. However, it is acknowledged that waiver is a different concept to the subject of this reference.
} 
an ilobolo agreement is a contract or agreement in favour of the notion that it is not a contract. On the other hand, the reasons for non-enforcement may be historical. ${ }^{58}$ The settlers looked down on customary marriages. They abhorred the practice of ilobolo and regarded it as the purchase of a woman. 59 This being the case, ilobolo agreements, historically, were not enforced in the courts. ${ }^{60}$ Even if they had been enforced, Roman-Dutch law or English law might have infiltrated them. If not infiltrated, they might have been caught in the crossfire in the ideological war between the Dutch and the British on which system of law should apply in the Cape of Good Hope, Natal, Transvaal and the Orange Free State. ${ }^{61}$ This may have been what prompted Hlophe to argue that ilobolo-related matters should not be adjudicated in a court of law. However, the preceding submission is made with doubt. ${ }^{62}$

\section{Social agreement}

Since not all agreements are contracts, a distinction must be drawn between a contract and other agreements - the so-called social agreements, gentlemen's agreements or moral or natural obligations. Sharrock submits that agreements made in a domestic, family and social context are not binding because the parties do not intend them to be. ${ }^{63}$ In other words, parties do not intend that a legal suit should follow should they not perform in terms of such an agreement. By implication, Sharrock's views leave out agreements in a commercial context. This is understandable, because the root of the law of contract appears to be in commerce rather than in a social setting. ${ }^{64}$

58 Dlamini (1984 CILSA 372) points out that s 182 of the 1891 Code barred any action for recovery of ilobolo for marriages already concluded. This provision was deeply resented by Black Africans.

59 Mndaweni 1990 CILSA 366.

60 It is important to add that the Xhosa people practised the custom of ukutheleka. In terms of this custom, if the father or guardian of the wife demands a reasonable amount of ilobolo, and the husband fails to deliver such, the father or guardian may take away the wife and her children back to her maiden home until such time that her husband complies with his obligation to pay ilobolo. See Ngema "The Enforcement of the Payment of Lobolo and Its Impact on Children's Rights in South Africa" 201316 PER 405 408. Whether the Zulus knew such practice is unclear to the author. However, the author is aware of a practice called "ukudla isibaya". In terms of this practice, a creditor could resort to self-help by taking away cattle belonging to a delinquent debtor. There were defined instances when "ukudla isibaya" could be resorted to. Probably, this practice is falling into disuse; see also Dlamini (A Juridical Analysis 323-324), who asserts that ukutheleka was only practised among the Xhosa and not the Zulus. He further submits that the Zulus saw the ilobolo agreement as a contract of good faith.

61 Van den Bergh "The Remarkable Survival of Roman-Dutch Law in Nineteenth-Century South Africa" 201218 Fundamina 71 73-81.

62 Hlophe 1984 CILSA 171. It is difficult to make out the author's reason for the submission that courts should be barred from adjudicating ilobolo matters. In light of the main idea of the article (the abolition of ilobolo practice), there is doubt that he intended to protect the sacred practice of ilobolo from the influence of foreign legal systems such as Roman-Dutch law and English law.

63 Sharrock Business Transactions Law 84.

64 Joubert General Principles 6 and Christie The Law of Contract 3-7. 
Certainly, ilobolo is something more than a mere social agreement. While it cannot be averred that ilobolo is a contract in the strict sense of the word, the willingness to comply with the agreement is, nevertheless, as noted above, present. The potential groom also creates the impression to his inlaws that he will deliver ilobolo as agreed. An agreement on ilobolo is a serious one. It has far-reaching legal, social and economic consequences; it unites families, establishes bonds among family ancestors and establishes the wife's status in her new family. One may add that it also establishes the husband's status in his wife's family (his new family). Therefore, it is difficult to reach a conclusion that an ilobolo agreement is a social agreement that merely attracts a moral obligation.

\section{Conclusion on the juristic nature of ilobolo}

To conclude that an ilobolo agreement is a contract could easily lead to the conclusion that it is a contract of sale in terms of which a wife is sold and bought - something that is repugnant. ${ }^{65}$ At the same time, reducing the meaning of ilobolo to a social agreement with very little, if any, juristic relevance undermines the entire practice. A conclusion on the juristic nature of ilobolo agreement is very important, because it spells out the consequences. For instance, some remedies for breach of contract are specific performance and damages. Should it be concluded that an ilobolo agreement is a contract, it follows that a person who fails to honour the agreement is in breach of contract and specific performance may be pleaded.

The issue of specific performance in the context of marriage evokes interest. Under the common law, specific performance has long been ruled out in cases of breach of promise to marry. ${ }^{66}$ Nonetheless, it is essential to be vigilant: legal developments under the common law are not binding on customary law. Customary law must be understood in its own terms and not through the lens of the common law. ${ }^{67}$ The guiding principles are constitutional norms such as equality, ${ }^{68}$ human dignity 69 and the right to culture $^{70}$ - read with the constitutional imperative to develop customary law, as stated in section 39(2) of the Constitution. ${ }^{71}$

65 Dlamini (A Juridical Analysis 319) concludes that an ilobolo agreement is a contract. However, he concedes that this contract has features that are foreign to the common law.

66 See Sibisi (2019 Obiter 342), who, in turn, cites Sepheri v Scanlan 2008 (1) SA 322 (C) 331 . By the $20^{\text {th }}$ century, it was no longer possible to claim specific performance for breach of promise to marry. Instead, the jilted party could claim damages in contract and delict. The contract claim was for actual loss incurred (wasted expenditure preparing for a wedding) and prospective loss (depending on the envisaged matrimonial property system). For the sake of clarity, it is accepted that it is no longer possible to claim for prospective loss. A jilted party could also claim for damages in delict provided that the manner in which the promise to marry was breached is objectively wrongful in the delictual sense.

$67 \quad M M v M N 2013$ (4) SA 415 (CC) 423.

68 S 9 of the Constitution of the Republic of South Africa, 1996 (the Constitution).

$69 \mathrm{~S} 10$ of the Constitution.

70 S 30 and 31 of the Constitution.

71 S 39(2) of the Constitution provides: "When interpreting any legislation, and when developing the common law or customary law, every court, tribunal or forum must promote the spirit, purport and objects of the Bill of Rights." 
Customary law must be distinguished from the common law on the issue of enforcement of an ilobolo agreement through specific performance. llobolo is unknown in the common law. ${ }^{72}$ Therefore the bar on specific performance in cases of breach of promise to marry cannot be sustained under customary law. Furthermore, it is not clear that a failure to pay ilobolo may be construed as a breach of promise to marry. All depends on the conduct of the parties. For instance, it is not uncommon for parties to continue living together as husband and wife in cases where the "husband" is failing to honour his obligation to pay ilobolo as per the agreement. It is difficult to reconcile the latter case with a breach of promise to marry.

It is therefore submitted that the juristic nature of an ilobolo agreement is that of an agreement sui generis with the essence of a contract in that the parties do seriously intend to be bound by the agreement. This agreement sui generis, which does appear to resemble a contract, is not one of sale. Instead, it is an innominate agreement in that it is unclassified. ${ }^{73}$ However, it is possible to enforce an ilobolo agreement since the amount agreed upon is always certain. ${ }^{74}$

\section{CONCLUSION}

Ilobolo is firmly entrenched in customary law. It has survived various intrusions, the earliest being the settlers' attitude towards the practice. They saw it as a sale contract, which it is not. It has also survived other negative and uninformed views, the latest being that the practice is unconstitutional in that it objectifies women. There are sections of our community calling for the complete abolition of the practice. Despite all these things, the practice of ilobolo remains undisturbed.

Ilobolo serves various functions. It serves a legal function in that it facilitates, among other things, the registration of a customary marriage. It also serves a social function in that it establishes a wife's status in her new family; it unites the two families as well as their ancestors. Ilobolo also serves a financial function. It provides funds to plan the wedding. In certain instances, it may provide financial security should the spouses encounter financial difficulties during the course of their marriage. A wife may go back to her guardian and ask for financial assistance; this is less likely to happen if ilobolo has not been paid in the first place.

It is essential to ascertain the juristic nature of ilobolo in South Africa. The conclusion reached above is that ilobolo is an agreement sui generis entered into by the parties with a serious intention to be bound. It is not a contract of sale, but an innominate agreement that is capable of being enforced through a remedy of specific performance.

Dlamini A Juridical Analysis 315.

Hutchison "Reciprocity in Contract Law" 20131 Stell LR 35.

74 This is to counter the difficulty with enforcing innominate agreements. See Hutchison 2013 Stell LR 5. See also Du Plessis "The Unilateral Determination of Price: A Question of Certainty or Public Policy" 201316 PER 6791. 